\title{
Hemodynamic Effects of Pentazocine in Acute Myocardial Infarction
}

Gerd Rettig, M.D., Hans-Dieter Hufnagl, M.D., Gerd Fröhlig, M.D., Hermann Schieffer, M.D., and Ludwig Bette, M.D.

\section{SUMMARY}

In 12 patients with acute myocardial infarction the hemodynamic effects of a single intravenous injection of $30 \mathrm{mg}$ of pentazocine were investigated. The administration of pentazocine resulted in no significant hemodynamic changes. In particular, there was no increase in peripheral vascular resistance and no evidence of decreased left ventricular function or respiratory depression. In the occasional patients who demonstrated an elevation of pulmonary arterial pressure, it was probably due to a direct effect of the drug on the pulmonary vasculature.

\section{Additional Indexing Words :}

Coronary heart disease Left ventricular function Systolic time intervals Pulmonary artery pressure

7 HE analgesic effect of pentazocine in patients with acute myocardial 1 infarction is well accepted. However, the hemodynamic effects of this drug remain controversial, particularly in patients with coronary heart disease.

Several investigators have observed that the administration of pentazocine resulted in a marked rise in mean pulmonary arterial pressure. This increase was considered to be a result of impaired left ventricular function which occurred as a consequence of the increased peripheral vascular resistance caused by the drug. ${ }^{11,101,14)}$ In contrast, other investigators have observed that pentazocine promoted only a slight increase in pulmonary arterial pressure and no effect on left ventricular function. ${ }^{13)(17)-19}$ )

In view of these conflicting reports and the obvious clinical importance of this problem, we investigated the hemodynamic effects of pentazocine under the conditions of our own coronary care unit.

\section{Methods}

Hemodynamic studies were performed on 12 patients (11 males, 1 female). The mean age of the group was 65 years (range $52-76$ years). All patients had

From the Medizinische Universitätsklinik und Poliklinik, Innere Medizin III, 6650 Homburg/ Saar, Germany.

Received for publication May 12, 1978. 
suffered from myocardial infarction 8 to 48 hours (mean 39 hours) prior to the study. Myocardial infarction was diagnosed by the combination of history of chest pain, characteristic ECG changes and typical elevations of pertinent serum enzymes. The infarction was anterior in 4 cases and inferior in the remaining 8 .

The clinical course was characterized by only slight to moderate left ventricular failure, no patient presented with cardiogenic shock or pulmonary edema.

Table I. Hemodynamics before and

\begin{tabular}{|c|c|c|c|c|c|c|c|}
\hline & & \multirow{2}{*}{\multicolumn{2}{|c|}{$\begin{array}{l}\text { Pre-period } \\
\text { mean values }\end{array}$}} & \multirow{2}{*}{\multicolumn{2}{|c|}{$0 \mathrm{~min}$}} & & \\
\hline & & & & & & \multicolumn{2}{|c|}{$5 \mathrm{~min}$} \\
\hline & & $\overline{\mathbf{x}}$ & $\pm s$ & $\overline{\mathbf{x}}$ & $\pm s$ & $\overline{\mathbf{x}}$ & $\pm s$ \\
\hline HR & $\left(\min ^{-1}\right)$ & 70.4 & 19.7 & 73.5 & 21.0 & 74.0 & 20.8 \\
\hline SBAP & $(\mathrm{mmHg})$ & 152 & 28 & 151 & 30 & 146 & 25 \\
\hline DBAP & $(\mathrm{mmHg})$ & 76 & 10 & 76 & 10 & 75 & 9 \\
\hline MBAP & $(\mathrm{mmHg})$ & 101 & 15 & 101 & 15 & 99 & 12 \\
\hline $\mathrm{CO}$ & $(1 / \mathrm{min})$ & 5.17 & 1.10 & 5.20 & 1.16 & 5.14 & 1.20 \\
\hline $\mathrm{CI}$ & $\left(\mathrm{l} / \mathrm{min} \cdot \mathrm{m}^{2}\right)$ & 2.80 & 0.55 & 2.81 & 0.58 & 2.78 & 0.57 \\
\hline SV & $(\mathrm{ml})$ & 64.4 & 16.5 & 62.8 & 18.1 & 61.7 & 17.5 \\
\hline SVI & $\left(\mathrm{ml} / \mathrm{m}^{2}\right)$ & 34.8 & 8.4 & 33.9 & 9.4 & 33.3 & 9.0 \\
\hline PVR & $\left(\right.$ dyne $\left.\cdot \mathrm{sec} \cdot \mathrm{cm}^{-5}\right)$ & 1,695 & 393 & 1,676 & 446 & 1,639 & 301 \\
\hline SPAP & $(\mathrm{mmHg})$ & 34.2 & 15.2 & 35.4 & 14.5 & 39.5 & 16.7 \\
\hline EDPAP & $(\mathrm{mmHg})$ & 12.4 & 7.1 & 13.2 & 7.3 & 15.5 & 7.8 \\
\hline MPAP & $(\mathrm{mmHg})$ & 20.0 & 9.4 & 21.1 & 8.9 & 23.7 & 10.1 \\
\hline TPR & $\left(\right.$ dyne $\left.\cdot \mathrm{sec} \cdot \mathrm{cm}^{-5}\right)$ & 362 & 277 & 392 & 324 & 426 & 272 \\
\hline LVSWI & $\left(\mathrm{Gm} \cdot \mathrm{m} / \mathrm{m}^{2}\right)$ & 46.6 & 14.5 & 44.7 & 13.1 & 41.7 & 11.8 \\
\hline MSER & $\left(\mathrm{ml} / \mathrm{sec} \cdot \mathrm{m}^{2}\right)$ & 12,945 & 2,590 & 12,509 & 3,035 & 12,191 & 2,520 \\
\hline $\mathrm{O}_{2} \mathrm{a}$ & $(\mathrm{mmHg})$ & 69.1 & 18.4 & 62.2 & 13.8 & 62.4 & 13.0 \\
\hline $\mathrm{O}_{2} \mathrm{v}$ & $(\mathrm{mmHg})$ & 34.8 & 4.7 & 34.8 & 6.7 & 35.1 & 5.9 \\
\hline $\mathrm{AVDO}_{2}$ & $(\mathrm{mmHg})$ & 34.2 & 17.7 & 27.3 & 12.7 & 27.2 & 11.0 \\
\hline $\mathrm{pH}$ & & 7.41 & 0.04 & 7.38 & 0.04 & 7.38 & 0.04 \\
\hline $\mathrm{pCO}_{2}$ & $(\mathrm{mmHg})$ & 41.5 & 6.0 & 46.1 & 5.7 & 45.2 & 8.2 \\
\hline St. Bic. & $(\mathrm{mVal} / \mathrm{l})$ & 25.4 & 2.9 & 26.0 & 3.3 & 25.5 & 2.4 \\
\hline LVET & (msec) & 262 & 34 & 259 & 37 & 258 & 38 \\
\hline PEP & (msec) & 89 & 17 & 90 & 21 & 90 & 21 \\
\hline$Q-1$ & (msec) & 57 & 10 & 57 & 10 & 57 & 10 \\
\hline IVCP & (msec) & 32 & 13 & 33 & 16 & 33 & 14 \\
\hline rel. LVET & $(\%)$ & 95.0 & 8.5 & 95.7 & 9.8 & 95.2 & 9.8 \\
\hline LVET/PEP & & 3.07 & 0.83 & 3.06 & 1.07 & 3.04 & 1.00 \\
\hline $\mathrm{DBAP} / \mathrm{IVCP}$ & $\left(\mathrm{mmHg} \cdot \mathrm{sec}^{-1}\right)$ & 2,636 & 858 & 2,550 & 757 & 2,410 & 972 \\
\hline
\end{tabular}

No statistical significance was obtained in any of the listed data.

Abbreviations: $\quad H R=$ Heart rate, $S B A P=$ Systolic brachial arterial pressure, $D B A P=$ Diastolic brachial arterial pressure, $\mathrm{MBAP}=$ Mean brachial arterial pressure, $\mathrm{CO}=\mathrm{Cardiac}$ output, $\mathrm{CI}$ = Cardiac index, SV=Stroke volume, SVI = Stroke volume index, $\mathrm{PVR}=$ Peripheral vascular resistance, $\quad \mathrm{SPAP}=$ Systolic pulmonary arterial pressure, DPAP = Diastolic pulmonary arterial pressure, $\mathrm{MPAP}=$ Mean pulmonary arterial pressure, $\mathrm{TPR}=$ Total pulmonary resistance, LVSWI 
All patients were in sinus rhythm except one who exhibited atrial fibrillation. Apart from isolated supraventricular and ventricular ectopics no other arrhythmias were observed.

All medication were discontinued at least 4 hours prior to the study except for a few cases in which previously started heparin infusion was maintained.

Under local anaesthesia a $7 F$ thermistor Swan-Ganz catheter (Edwards Lab-

after Penta zocine

Mean $(\overline{\mathbf{x}})$ and standard deviations $( \pm \mathrm{s})$.

\begin{tabular}{|c|c|c|c|c|c|c|c|c|c|}
\hline \multicolumn{10}{|c|}{ After pentazocine } \\
\hline \multicolumn{2}{|c|}{$10 \mathrm{~min}$} & \multicolumn{2}{|c|}{$15 \mathrm{~min}$} & \multicolumn{2}{|c|}{$20 \mathrm{~min}$} & \multicolumn{2}{|c|}{$25 \min$} & \multicolumn{2}{|c|}{$30 \mathrm{~min}$} \\
\hline$\overline{\mathbf{x}}$ & $\pm s$ & $\overline{\mathbf{x}}$ & $\pm \mathrm{s}$ & $\overline{\mathbf{x}}$ & $\pm s$ & $\bar{x}$ & $\pm s$ & $\overline{\mathbf{x}}$ & $\pm s$ \\
\hline 73.0 & 20.9 & 75.2 & 21.0 & 74.3 & 20.9 & 73.1 & 20.7 & 72.6 & 20.7 \\
\hline 144 & 24 & 146 & 26 & 144 & 23 & 148 & 22 & 147 & 24 \\
\hline 75 & 10 & 76 & 10 & 76 & 9 & 77 & 9 & 76 & 11 \\
\hline 99 & 13 & 99 & 13 & 99 & 12 & 102 & 12 & 100 & 14 \\
\hline 5.28 & 1.18 & 5.09 & 1.16 & 5.14 & 1.11 & 5.12 & 1.12 & 5.21 & 1.11 \\
\hline 2.85 & 0.56 & 2.75 & 0.53 & 2.78 & 0.52 & 2.77 & 0.52 & 2.81 & 0.53 \\
\hline 64.6 & 18.3 & 60.7 & 15.9 & 62.5 & 15.8 & 63.3 & 15.9 & 65.4 & 17.6 \\
\hline 34.9 & 9.6 & 32.8 & 7.9 & 33.8 & 8.1 & 34.2 & 8.2 & 35.3 & 9.2 \\
\hline 1,598 & 268 & 1,684 & 317 & 1,652 & 318 & 1,701 & 300 & 1,645 & 267 \\
\hline 39.8 & 16.4 & 39.8 & 17.0 & 40.1 & 15.3 & 40.0 & 16.3 & 39.3 & 14.6 \\
\hline 16.0 & 7.3 & 15.7 & 7.4 & 15.7 & 7.6 & 15.8 & 7.6 & 15.3 & 7.7 \\
\hline 24.2 & 10.0 & 24.4 & 10.1 & 24.0 & 9.6 & 24.3 & 10.0 & 23.4 & 9.6 \\
\hline 423 & 267 & 434 & 272 & 422 & 265 & 438 & 280 & 412 & 267 \\
\hline 43.6 & 12.2 & 41.4 & 11.4 & 42.2 & 12.0 & 44.1 & 12.6 & 45.5 & 13.0 \\
\hline 12,620 & 2,542 & 12,100 & 2,440 & 12,295 & 2,347 & 12,350 & 2,438 & 12,470 & 2,395 \\
\hline 62.4 & 13.2 & 63.9 & 12.9 & 63.5 & 12.5 & 64.9 & 13.0 & 65.3 & 14.0 \\
\hline 35.9 & 5.7 & 36.2 & 5.9 & 35.7 & 6.6 & 35.4 & 6.4 & 35.8 & 6.4 \\
\hline 26.4 & 11.2 & 27.5 & 11.2 & 27.8 & 10.5 & 29.1 & 11.4 & 30.2 & 11.6 \\
\hline & & 7.39 & 0.04 & & & 7.37 & 0.04 & & \\
\hline & & 45.9 & 7.9 & & & 46.9 & 8.6 & & \\
\hline & & 25.8 & 2.7 & & & 25.0 & 2.7 & & \\
\hline 262 & 40 & 260 & 37 & 263 & 36 & 265 & 40 & 268 & 39 \\
\hline 78 & 25 & 90 & 22 & 90 & 21 & 89 & 22 & 89 & 23 \\
\hline 57 & 11 & 58 & 12 & 57 & 10 & 57 & 9 & 58 & 12 \\
\hline 30 & 19 & 32 & 15 & 33 & 15 & 32 & 17 & 31 & 19 \\
\hline 96.1 & 10.0 & 96.3 & 10.0 & 96,8 & 9.5 & 97.0 & 10.0 & 97.5 & 9.8 \\
\hline 3.37 & 1.68 & 3.12 & 1.26 & 3.08 & 0.95 & 3.16 & 1.05 & 3.24 & 1.18 \\
\hline 3,334 & 2,379 & 2,727 & 945 & 2,584 & 963 & 2,914 & 1,526 & 3,139 & 1,480 \\
\hline
\end{tabular}

$=$ Left ventricular stroke work index, $\mathrm{MSER}=$ Mean systolic ejection rate, $\mathrm{O}_{2} \mathrm{a}=$ Arterial $\mathrm{O}_{2}$ tension, $\mathrm{O}_{2} \mathrm{v}=$ Mixed venous $\mathrm{O}_{2}$ tension, $\quad A V D \mathrm{O}_{2}=$ Arterio-venous $\mathrm{O}_{2}$ difference, $\mathrm{pCO}_{2}=$ Arterial $\mathrm{CO}_{2}$ tension, St. Bic. =Standard bicarbonate, LVET $=$ Left ventricular ejection time, $\mathrm{PEP}=$ Pre-ejection period, Q-1=Electromechanical latency, IVCP = Isovolumic contraction period, rel. $\mathrm{LVET}=\mathrm{LVET}$ normalized for heart rate. 
oratories, Santa Ana, California, USA) was inserted either percutaneously or by cutdown procedure into an antecubital vein and passed into the pulmonary artery. A cannula was introduced into the brachial artery (Still Infusion Cannula). For pressure recordings Statham $\mathrm{P}$ Db 23 pressure transducers were used, the zero reference point being set at midthoracic level. Pulmonary arterial and brachial arterial pressures were recorded simultaneously with the electrocardiogram, the external carotid pulse tracing and the phonocardiogram on a 6-channel jet inscription polygraph (Mingograph Cardirex, Siemens). Cardiac output was determined by the thermal dilution technique using a cardiac output computer (Fischer, Göttingen); the mean values from quadruplicate measurements in each instance were used. Determination of arterial and central venous oxygen tension and arterial blood gases ( $\mathrm{pH}, \mathrm{pCO}_{2}$, standard bicarbonate) was carried out with the systems BMS 2, MK 2, and BEU 1 from Radiometer, Copenhagen. The systolic time intervals were calculated according to Blumberger ${ }^{2), 3)}$.

From the measured parameters the following were calculated :-

Peripheral vascular resistance and total pulmonary resistance, using standard definitions, in addition left ventricular stroke work index (LVSWI) and mean systolic ejection rate (MSER) according to the following formulae:

$$
\begin{aligned}
\text { LVSWI }= & \frac{(\text { MBAP-EDPAP }) \times \text { SVI } \times 1.36 \times 1.055}{100}\left[\mathrm{Gm} \times \mathrm{m} / \mathrm{m}^{2}\right] \\
\text { MSER }= & \frac{\text { SVI } \times 100}{\text { LVET }}\left[\mathrm{ml} / \mathrm{sec} . \mathrm{m}^{2}\right] \\
\text { MBAP }= & \text { mean brachial arterial pressure }(\mathrm{mmHg}) \\
\text { EDPAP }= & \text { end diastolic pulmonary arterial pressure }(\mathrm{mmHg}) \\
\text { SVI }= & \text { stroke volume index }\left(\mathrm{ml} / \mathrm{m}^{2}\right) \\
\text { LVET }= & \text { left ventricular ejection time (sec), measured from the carotid pulse } \\
& \text { curve or the arterial pressure tracing. }
\end{aligned}
$$

In calculating the left ventricular stroke work index, the end diastolic pulmonary arterial pressure was used as an indirect parameter for the left ventricular filling pressure, since corresponding comparative measurements have shown a good correlation ( $\mathrm{r}=0.93$ ) even in acute myocardial infarction. ${ }^{8)}$

In all patients $30 \mathrm{mg}$ pentazocine was injected intravenously within $2 \mathrm{~min}$. Measurements were taken 15, 10,5, and 0 min before the administration of the drug and $0,5,10,15,20,25$, and $30 \mathrm{~min}$ afterwards. From all values before the administration of the drug an initial mean value was calculated for each patient and compared with the values after the administration of pentazocine.

Statistical analysis was performed using Student's t-test for paired data.*** A significant difference was assumed if the bilateral probability of error was less than $5 \%(2 \mathrm{p}<0.05)$.

* CD 3105-Computer from the Computer Center of the University of the Saarland, Homburg terminal-supported by the DFG.

** We are grateful to Herr Akad. Oberrat Dipl.-Math. W. Heinrich and Herr Dipl.-Math. Gräber for their assistance in the statistical evaluation of the test results. 


\section{Results}

Table I shows the hemodynamic effects of pentazocine in the 12 patients with recent myocardial infarction.

There was no change in heart rate, blood pressure, cardiac index, stroke volume, or peripheral vascular resistance.

The changes in pulmonary arterial pressure were inconsistent with the mean pulmonary arterial pressure showing an insignificant increase from $20.0 \pm 9.4$ to $24.4 \pm 10.1 \mathrm{mmHg}$. There was no significant change in pulmonary vascular resistance. However, in isolated cases, an increase in pulmonary arterial pressure by a maximum of $18 \mathrm{mmHg}$ (systolic) and $11 \mathrm{mmHg}$ (diastolic) could be observed.

In view of the lack of change in measured parameters the calculated parameters LVSWI and MSER also showed no change.

Following the administration of pentazocine the arterial $\mathrm{O}_{2}$ tension fell by a mean of $6.7 \mathrm{mmHg}$ in the first $10 \mathrm{~min}$. Since the mixed venous oxygen tension remained constant there was a temporary drop in $\mathrm{AVDO}_{2}$. The arterial $\mathrm{CO}_{2}$ tension tended to increase and the $\mathrm{pH}$ tended to fall with the standard bicarbonate remaining constant. However, none of the changes in blood gases were significant.

In a similar manner to other measurements pentazocine caused no change in systolic time intervals and in particular there was no alteration of

Table II. Hemodynamics before and after Pentazocine

\begin{tabular}{|c|c|c|c|c|c|c|c|c|c|}
\hline & $\begin{array}{l}\text { Pre- } \\
\text { period } \\
\text { mean } \\
\text { values }\end{array}$ & $0 \mathrm{~min}$ & $5 \mathrm{~min}$ & $10 \mathrm{~min}$ & $15 \mathrm{~min}$ & $20 \mathrm{~min}$ & $25 \mathrm{~min}$ & $30 \mathrm{~min}$ \\
\hline SBAP & $(\mathrm{mmHg})$ & 153 & 154 & 150 & 152 & 149 & 248 & 152 & 156 \\
\hline DBAP & $(\mathrm{mmHg})$ & 74 & 76 & 76 & 77 & 75 & 75 & 79 & 80 \\
\hline MBAP & $(\mathrm{mmHg})$ & 100 & 102 & 102 & 105 & 103 & 102 & 108 & 107 \\
\hline SVI & $\left(\mathrm{ml} / \mathrm{m}^{2}\right)$ & 37.5 & 37.0 & 35.1 & 38.5 & 36.0 & 37.2 & 37.5 & 38.4 \\
\hline \multicolumn{2}{|c|}{ PVR (dyne. $\mathrm{sec} \cdot \mathrm{cm}^{-5}$ ) } & 1,587 & 1,524 & 1,597 & 1,516 & 1,548 & 1,481 & 1,567 & 1,572 \\
\hline SPAP & $(\mathrm{mmHg})$ & 32.1 & 36.5 & 42.7 & 46.0 & 46.2 & 45.5 & 45.7 & 43.5 \\
\hline EDPAP & $(\mathrm{mmHg})$ & 11.2 & 13.2 & 16.5 & 18.7 & 18.0 & 17.2 & 18.5 & 18.0 \\
\hline MPAP & $(\mathrm{mmHg})$ & 18.6 & 21.5 & 25.2 & 28.2 & 28.0 & 26.5 & 28.0 & 23.7 \\
\hline \multicolumn{2}{|c|}{ TPR (dyne. sec. $\mathrm{cm}^{-5}$ ) } & 288 & 313 & 393 & 506 & 417 & 385 & 408 & 386 \\
\hline LVSWI & $\left(\mathrm{Gm} \cdot \mathrm{m} / \mathrm{m}^{2}\right)$ & 47.8 & 46.6 & 42.8 & 47.6 & 43.4 & 44.8 & 48.0 & 49.1 \\
\hline MSER & $\left(\mathrm{ml} / \mathrm{sec} \cdot \mathrm{m}^{2}\right)$ & 13,909 & 13,640 & 13,099 & 14,012 & 13,314 & 13,585 & 13,739 & 13,744 \\
\hline IVCP & (msec) & 37 & 36 & 35 & 31 & 33 & 36 & 37 & 34 \\
\hline \multicolumn{2}{|c|}{$\begin{array}{l}\mathrm{DBAP} / \mathrm{IVCP} \\
\left(\mathrm{mmHg} \cdot \mathrm{sec}^{-1}\right)\end{array}$} & 1,497 & 1,717 & 1,672 & 4,510 & 2,832 & 2,607 & 2,640 & 3,292 \\
\hline
\end{tabular}

Patients with an increase in MPAP by $>8 \mathrm{mmHg}(\mathrm{N}=4)$. Mean values, symbols as Table 1 . 
the DBAP/IVGP ratio.

There was a small sub-group of patients who demonstrated an increase of mean pulmonary arterial pressure greater than $8 \mathrm{mmHg}$. This group did not differ from the total group regarding changes in systemic arterial pressure, peripheral vascular resistance, LVSWI, MSER, or DBAP/IVGP ratio (Table II).

\section{Discussion}

Our results confirm the findings of others ${ }^{7), 16), 19)}$ that, in patients with acute myocardial infarction, the administration of $30 \mathrm{mg}$ of pentazocine resulted in no significant hemodynamic changes.

Other investigators have observed an increased pulmonary arterial pressure following the administration of pentazocine. ${ }^{1,101,14), 17), 19)}$ They have considercd this increase to be a primary effect on the pulmonary vasculature $^{17), 19)}$ or a secondary effect caused by an elevation of left ventricular filling pressure. The latter was thought to occur as a result of an increased afterload on the left ventricle. ${ }^{1), 10), 14)}$

Our data indicate that any elevation in pulmonary arterial pressure was inconsistent and, in considering the whole group of patients, was statistically insignificant.

Although we did not directly measure left ventricular pressure it was unlikely that left ventricular filling pressure was altered due to an afterload induced reduction in left ventricular function. There was no change in peripheral vascular resistance which had been observed by several authors. ${ }^{1), 10) \text {, }}$ 12),13),15),16) In addition, pentazocine caused no alterations in the indirect measurements of left ventricular function, that is, LVSWI, MSER, or the DBAP/IVCP ratio.

In considering the potential constricting effects of pentazocine on the pulmonary resistance vessels, previous investigators have invoked the EulerLiljestrand reflex and the respiratory depressant effect of pentazocine. ${ }^{4)-6), 9), 11 \text {, }}$ Our data indicate little if any respiratory depression shown by the insignificant changes in arterial $\mathrm{PO}_{2}, \mathrm{pCO}_{2}$ and $\mathrm{pH}$. Thus, in those patients who showed an increase in pulmonary arterial pressure it was likely a direct effect of pentazocine on the pulmonary resistance vessels.

\section{REFERENCES}

1. Alderman EL, Barry WH, Graham AF, Harrison DG: Haemodynamic effects of morphine and pentazocine differ in cardiac patients. New Engl J Med 34: 244, 1972 
2. Blumberger K: Die Anspannungszeit und Austreibungszeit beim Menschen. Arch Kreislaufforsch 6: 203, 1940

3. Blumberger K: Die Untersuchung der Dynamik des Herzens beim Menschen. Ergebn Inn Med Kinderheilk 62: 424, 1942

4. Davie J, Scott DB, Stephen GW: Respiratory effects of pentazocine and pethidine in patients anaesthetized with halothane and oxygen. Brit J Anaesth 42: 113, 1970

5. Davie J, Stephen GW, Scott DB: The effects of premedication with pentazocine and pethidine on respiration during general anaethcsia. Brit $J$ Anacsth 43: 500, 1971

6. Engineer $S$, Jeninet $S$ : Respiratory depression following single and repeated doses of pentazocine and pethidine. Brit J Anaesth 44: 795, 1972

7. Grossmann JA, Enselberg CD: A clinical trial of pentazocine analgesia in acute myocardial infarction and acute coronary insufficiency. Curr Ther Res 13: 505, 1971

8. Hanrath O, Bleifeld W, Mathey D, Merz W: Akuter Myokardinfarkt. IX. Die Bedeutung der Pulmonalarteriendruck-Überwachung für Prognose und Therapie. Dtsch med Wschr 99: 219,1973

9. Jennet S, Barker J, Forrest JB: A double-blind controlled study of the effects on respiration of pentazocine, phenoperidine and morphine in normal man. Brit J Anaesth 40: 864, 1968

10. Jewitt DE, Maurer JB, Hubner JPB: Increased pulmonary arterial pressures after pentazocine in myocardial infarction. Brit med J 1: 795, 1970

11. Keats AS, Telford J: Studies on analgesic drugs. VIII. A narcotic antagonist analgesic without psychomimetic effects. J Pharmacol exp Ther 143: 157, 1964

12. Lal S, Savidge RS, Chharbra GP: Cardiovascular and respiratory effects of morphine and pentazocine in patients with myocardial infarction. Lancet 1:379, 1969

13. Nagle R, Pilcher J: Respiratory and circulatory effects of pentazocine. Brit Heart $\mathrm{J}$ 34: 244,1972

14. Rickards AF, Smithen CS, Sowton E: Haemodynamic effects of pentazocine following acute myocardial infarction. Ann Clin Res 3: 199, 1971

15. Scott ME, Orr R: Effects of Diamorphine, Methadone, Morphine and Pentazocine in patients with suspected acute myocardial infarction. Lancet 1: 1065, 1969

16. Scott ME, Adgey AAJ: Circulatory effects of intravenous pentazocine in patients with acute myocardial infarction. Curr Ther Res 13: 81, 1971

17. Spiller P, Both A, Mertens HH, Schelbert HR, Kreuzer H: Die Wirkung von Pentazocin (Fortral) auf den kleinen Kreislauf. Med Welt 24: 1002, 1973

18. Tauchert M. Behrenbeck DW, Schulten HK, Chriske HW, Hellwig H, Hilger HH: Die Beeinflussung von System-, Lungen- und Koronarkreislauf durch Pentazocin (Fortral). Intensivmedizin 11: 229, 1974

19. Tauchert M, Anschütz F, Barckow D, Bette L, Dienstl F, Frederking H, Froer KL, Hilger HH, Jehle J, Kaindl K, Kreuzer H, Kühn P, Lerche D, Loddenkemper R, Loogen F, Oberhoffer G, Rettig G, Rudolph W, Spiller P: Der Einfluss von Pentazocin auf Kreislauf und Atmung. Herz-Kreisl 7: 178, 1975 